\title{
The cotton mealybug Phenacoccus solenopsis Tinsley (Hemiptera: Pseudococcidae) as a new insect pest on tomato plants in Egypt
}

\author{
Samah Sayed Ibrahim ${ }^{1}$, Fatma Abdelhalim Moharum ${ }^{1}$, Nesreen Mohamed Abd El-Ghany2*
}

\author{
${ }^{1}$ Plant Protection Research Institute, Agricultural Research Center, 7 Nadi El-Seid St., Dokki, Giza, Egypt \\ ${ }^{2}$ Pests and Plant Protection Department, National Research Centre, 33 El-Bohouth St., Dokki, Giza 12622, Egypt
}

Received: September 10, 2014

Accepted: February 4, 2015

\begin{abstract}
Recently, the mealybug Phenacoccus solenopsis Tinsley (Hemiptera: Pseudococcidae) was recorded as a new pest on tomato plants (Lycopersicon esculentum Mill) growing in Egypt. The mealybugs specimens were collected from tomato plants in the Qalyoubia governorate during summer season of 2014. The mealybug was identified as P. solenopsis based on the morphological characters and taxonomic key of this species. This study represents the first record of $P$. solenopsis as a new insect pest attacking tomato plants in Egypt.
\end{abstract}

Key words: Lycopersicon esculentum, mealybug, Phenacoccus solenopsis

\section{Introduction}

In less than a century, tomato (Lycopersicon esculentum Mill) (Family: Solanaceae) has become a major world food crop. Today, tomatoes are grown commercially in 159 countries. The major producers of tomatoes, in 2009 were China, the United States, India, Turkey, Egypt, Italy, and Iran. In Egypt, the tomato is considered one of the most important vegetable crops for fresh consumption and processing (Abd El-Ghany 2011). According to FAOSTAT, in 2012, Egypt ranked as one of the top producers of tomatoes $(8,625,219 \mathrm{t}$ were produced). The cultivated area of tomato in Egypt increased considerably during the last two decades. In 2011, the total cultivated area, and productivity of tomato in Egypt, was estimated by 505,823 feddan, yielding 805,3701 tons with an average of 15.92 tons/feddan (Anonymous 2011). According to the last estimates from the Egyptian Ministry of Agriculture and Land Reclamation in 2013, the tomato acreage increased to 16.636 tons/feddan with a total yield of $8,571,050$ tons from a total area of 515,225 feddan (Anonymous 2012). Tomato plants are subjected to infestation with several insect pests: cutworms, aphids, cabbage loppers, whiteflies, tomato fruit worms, and flea beetles (Ibrahim 2007; Abd El-Ghany 2011).

Mealybugs (Hemiptera: Pseudococcidae) are important insect pests worldwide (Williams 1985; Williams and Granara de Willink 1992; Miller et al. 2005; Hodgson et al. 2008; Abbas et al. 2009; Khuhro et al. 2012). The genus Phenacoccus currently contains about 180 species and is one of the largest genera in the Pseudococcidae (BenDov 1994). The cotton mealybug Phenacoccus solenopsis was originally described from the USA in 1898. Until 1992, this insect was known only in the USA, where it was widespread (Ben-Dov 2004). Phenacoccus solenopsis was reported in Central America, the Caribbean, and Ecuador (Fuchs et al. 1991; Williams and Granara de Willink 1992). The cotton mealybug $P$. solenopsis, is a polyphagous insect feeding on more than 200 plant species. There are plant species assigned to approximately 60 families. The insect has a preference for Asteraceae, Euphorbiaceae, Fabaceae, Malvaceae and Solanaceae. As an important insect pest, this insect has an economic and environmental impact. Large populations of mealybugs cause general weakening, defoliation, and death of susceptible plants. Indirectly, it may also damage plants by serving as vectors of plant diseases. Moreover, the honeydew excreted by the mealybugs causes growth of sooty moulds and other secondary infections that decreases photosynthesis and reduces the marketability of plant products. The cotton mealybug $P$. solenopsis, has a wide geographical distribution with its origin in Central America (Fuchs et al. 1991; Williams and Granara 1992), the Caribbean, Ecuador (Ben-Dov 1994), Chile (Larrain 2002), Argentina (Granara de Willink 2003), and Brazil (Culik and Gullan 2005). Phenacoccus solenopsis was described as a serious and invasive pest of cotton in Pakistan and India (Hodgson et al. 2008) and on Hibiscus rosasinensis (L.) in Nigeria (Akintola and Ande 2008). In Egypt, the occurrence of $P$. solenopsis infestation was recorded on weed plants by Abd-Rabou et al. (2010). 

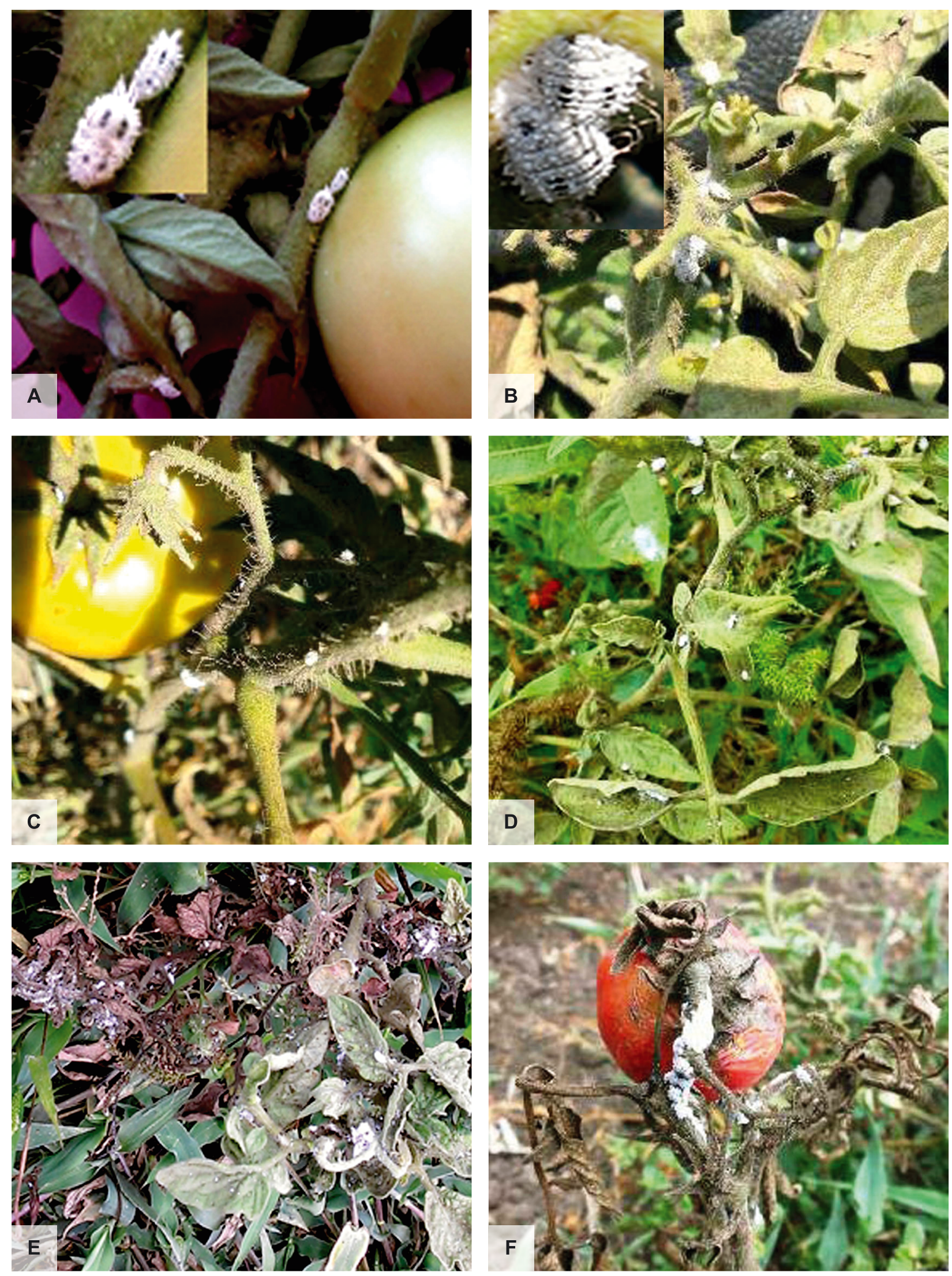

Fig. 1. Photographs showing the infestation of Phenacoccus solenopsis on tomato plants: A - adult and nymphs of P. solenopsis on stem and leaves of the tomato plant (photo: Dr. Samah Sayed); B - photograph showing P. solenopsis infesting the apical region of a tomato plant, and a magnified view of an adult female located at the top corner of the photo (photo: Dr. Nesreen Abd El-Ghany); C adult female of $P$. solenopsis and infested tomato plants. Seen are the infested stem, flower, and based buttons of the fruit (photo: Dr. Nesreen Abd El-Ghany); D - deformation and distortion symptoms of the infested tomato plant (photo: Dr. Nesreen Abd El-Ghany); E - heavy P. solenopsis infestation associated with twisting and curling of the terminal region of stems (arrow) and appearance of leaf wrinkling and puckering (head arrow) (photo: Dr. Nesreen Abd El-Ghany); F - noticeable damage of the tomato plant due to large populations of P. solenopsis nymphs and adults causing plant death (photo: Dr. Nesreen Abd El-Ghany) 


\section{Materials and Methods}

Mealybug specimens were collected from various tomato plants at Qaha Research station (Plant Protection Research Institute) from June to August 2014, to identify the species present in this area. Mealybug specimens were collected when noticed on plants during the fieldwork of the first and third authors. The specimens were identified by the second author at the Scale Insect Department, Plant Protection Research Institute, Agriculture Research Center, the Ministry of Agriculture. Mealybug specimens were slide-mounted for identification using the method outlined in Williams and Granara (1992). Identification of the genus was carried out using the key of the Pseudococcidae family (Hemiptera: Coccoidea) according to Mohammad and Moharum (2012).

\section{Results and Discussion}

The present study represents the first record in Egypt, of tomato plant infestations by the cotton mealybug. The mealybug specimens were collected from the tomato fields in the Qaha Research Station during the 2014 summer season. The mealybug was identified as P. solenopsis Tinsley (Hemiptera: Sternorrhyncha: Coccoidea: Pseudococcidae) using Mohammad and Moharum (2012) taxonomic key. Different photos of P. solenopsis, and photographs of the infestation on tomato plants are illustrated in figure 1 . The cotton mealybug $P$. solenopsis has not been previously noted as a pest of tomato in Egypt. The occurrence of $P$. solenopsis infestation in Egypt was recorded only on weed plants by Abd-Rabou et al. (2010). So, the present study is the first published record of tomato as a new host for P. solenopsis in Egypt.

The cotton mealybugs were reported on different host plant species worldwide including, field crops, vegetables, ornamentals, weeds, bushes and trees (Williams and Granaram 1992; Ben-Dov 1994; Larrain 2002; Granara de Willink 2003; Culik and Gullan 2005; Hodgson et al. 2008; Aheer et al. 2009; Arif et al. 2009; Abbas et al. 2010; Beltra and Soto 2011). The mealybugs were reported on 28 host plant species comprising 10 families in Sri-Lanka. This includes the major field crops of the Malavaceae, Solanaceae and Amaranthaceae families (Prishanthini and Vinobaba 2011). As mentioned before, this study represents the first evidence of the occurrence of the cotton mealybug P. solenopsis on tomato plants as a new host in Egypt, for this insect pest. Further reports on the occurrence of $P$. solenopsis have been documented on tomato plants from several countries. For example, $P$. solenopsis was first identified in a sample of tomato plants (Solanum lycopersicum L.) collected in October 2003 in the city of Vitória, in Brazilian state Espírito Santo (Culik and Gullan 2005).

The mealybug infestation attacking tomato plants was initially noticed in 19 June 2014. Adults and nymphs of this pest weaken the plants by sucking sap from the leaves, stems, roots, and fruits of the plant. A magnified view of the mealybug $P$. solenopsis, showing its morphological character is illustrated in figure $1 \mathrm{~A}$ and B. Morphologically, the adult female of $P$. solenopsis is wingless, the oval-shaped body often quite large $(5 \mathrm{~mm})$, somewhat rounded in lateral view, covered with white hydrophobic mealy wax filaments (18 short lateral and slightly longer terminal wax filaments). There are paired dark spots and/ /or stripes on the thorax and abdomen, which appeared as dark longitudinal lines. The adult male is blackish brown in color, about $1 \mathrm{~mm}$ long with a single pair of transparent wings. Male pupas are covered in a loose white silky cocoon. Two abdominal filaments of white wax projections occur at the end of the body. The adult male has no feeding mouthparts and causes no damage.

The infestation of $P$. solenopsis was observed on all parts of the tomato plants during the fieldwork of the present study (Fig. 1). The infestation appeared on stems, leaves, and sites where the metabolism is accelerated, such as the terminal bud, based buttons, and flowers (Fig. $1 \mathrm{~B}$ and $\mathrm{C})$. Similar findings were described by Osborne (2005), Culik and Gullan (2005), and Silva (2012). Affected tomato plants were also found to exhibit clear symptoms of deformation and distortion of the terminal growth (arrows in Fig. 1D and E). Moreover, noticeable foliar yellowing, leaf wrinkling and puckering were observed in figure 1E (head arrow). Osborne (2005) and Silva (2012) recorded the same implications on tomato plants during their work. Growing populations of mealybugs caused severe damage to the plants, serving to help the growth of sooty moulds and causing plant death (Fig. 1F). These findings agreed with the symptoms recorded by Jagadish et al. (2009). Therefore, a noticeable decrease in the production of tomato plants was recorded. Also, the lack of previous records of this insect pest ( $P$. solenopsis) combined with findings of well-established populations on tomato plants; indicate that the mealybug may soon become an important insect pest attacking tomato plants in Egypt. With this in mind, the present study highlights the need for additional surveys and further research on this species and its damage on such an economically important crop. Moreover, the challenge is to develop suitable management programs with less use of chemicals. A program with less use of chemicals would be necessary for important economic, health, and environmental impacts. Such a program for this insect pest then becomes warranted.

\section{References}

Abbas G., Arif M.J., Ashfaq M., Aslam M., Saeed S. 2010. Host plants distribution and overwintering of cotton mealybug (Phenacoccus solenopsis, Hemiptera: Pseudococcidae). International Journal of Agriculture and Biology 12 (3): 421-425.

Abbas G., Arif M.J., Saeed S., Karar H. 2009. A new invasive species of genus Phenacoccus Cockerell attacking cotton in Pakistan. International Journal of Agriculture and Biology 11 (1): 54-58.

Abd El-Ghany N.M. 2011. Molecular evaluation of Bacillus thuringiensis isolates from the soil and production of transgenic tomato plants harboring $B t$ gene for controlling lepidopterous insects in Egypt. Ph.D. thesis, Faculty of Science, Ain Shams University, Cairo, Egypt, 270 pp.

Abd-Rabou S., Germain J.F., Malausa T. 2010. Phenacoccus parvus Morrison et $P$. solenopsis Tinsley, deux Cochenilles nouvelles 
pour l'Egypte (Hemiptera: Pseudococcidae). Bulletin de la Société Entomologique de France 115 (4): 509-510.

Aheer J.H., Shah Z., Saeed M. 2009. Seasonal history and biology of cotton mealybug, Phenacoccus solenopsis Tinsley. Journal of Agriculture Results 47 (4): 423-431.

Akintola A.J., Ande A.T. 2008. First record of Phenacoccus solenopsis Tinsley (Hemiptera: Pseudococcidae) on Hibiscus rosasinensis in Nigeria. Agricultural Journal 3 (1): 1-3.

Anonymous 2011. Agricultural Statistics Bulletin. Central Administration of Economic. Ministry of Agriculture, Egypt, $184 \mathrm{pp}$.

Anonymous 2013. Agricultural Statistics Bulletin. Central Administration of Economic. Ministry of Agriculture, Egypt, $170 \mathrm{pp}$.

Arif M.I., Rafiq M., Ghaffar A. 2009. Host plants of cotton mealybug (Phenacoccus solenopsis): a new menace to cotton agroecosystem of Punjab, Pakistan. International Journal of Agriculture and Biology 11 (2): 163-167.

Beltra A., Soto A. 2011. New records of mealybugs (Hemiptera: Pseudococcidae) from Spain. Phytoparasitica 39 (4): 385-387.

Ben-Dov Y.A. 1994. Systematic Catalogue of the Mealybugs of the World (Insecta: Homoptera: Coccoidea: Pseudococcidae and Putoidae). Intercept Ltd, 686 pp.

Culik M.P., Gullan P.J. 2005. A new pest of tomato and other records of mealybugs (Hemiptera: Pseudococcidae) from Espírito Santo, Brazil. Zootaxa 964: 1-8.

Fuchs T.W., Stewart J.W., Minzenmayer R., Rose M. 1991. First record of Phenacoccus solenopsis Tinsley in cultivated cotton in the United States. Southwestern Entomologist 16 (3): 215-221.

Granara W. 2003. Nuevas citas y huéspedes de Phenacoccuspara la Argentina (Hemiptera: Pseudococcidae). [New records and quests of the Argentina Phenacoccuspara (Hemiptera: Pseudococcidae)]. Revista de la Sociedad Entomológica Argentina 62 (3/4): 80-82. (in Spanish with English summary)

Hodgson C.J., Abbas G., Arif M.J., Saeed S., Karar H. 2008. Phenacoccus solenopsis Tinsley (Sternorrhyncha: Coccoidea: Pseudococcidae), an invasive mealybug damaging cotton in Pakistan and India, with a discussion on seasonal morphological variation. Zootaxa 1913: 1-35.
Jagadish K.S., Shadhanaikural A., Chandru R., Shadakshari Y. 2009. Biochemical and morphological changes due to mealybug Phenacoccus solenopsis Tinsley (Homoptera: Pseudococcidae) infestation on sunflower (Helianthus annuus L.). Insect Environment 15 (1): 28-30.

Ibrahim S.S. 2007. Influence of agricultural practices on certain biological aspects and damage assessment of tomato fruit worm and tomato semi-looper. M.Sc. thesis, Faculty of Agriculture, Cairo University, Cairo, Egypt, 160 pp.

Khuhro S.N., Kalroo A.M., Mahmood R. 2012. Present status of mealy bug Phenacoccus solenopsis (Tinsley) on cotton and other plants in Sindh (Pakistan). p. 268-271. In: Book of Papers. World Cotton Research Conference - 5, Mumbai, 07-11 November 2011, 580 pp. https://www.icac. org/meetings/wcrc/ wcrc5/Proceedings.pdf

Larrain S.P. 2002. Insect and mite pest incidence on sweet pepinos Solanum muricatum (Ait.) cultivated in the IV Region, Chile. Agricultura Tecnica 62 (1): 15-26.

Miller D.R., Miller G.L., Hodges G.S., Davidson J.A. 2005. Introduced scale insects (Hemiptera: Coccoidea) of the United States and their impact on U.S. agriculture. Proceedings of the Entomological Society of Washington 107 (1): 123-158.

Mohammad Z.K., Moharum F.A. 2010. Key to the genus of family Pseudococcidae (Hemiptera: Coccoidea) in Egypt. Egyptian Academic Journal of Biological Science 5 (3): 1-5.

Osborne L.S. 2005. Mealybugs. http://www.mrec.ifas.ufl.edu/ lso/Mealybugs.htm. [Accessed: March 1, 2014].

Prishanthini M., Vinobaba M. 2011. A survey of mealybugs and their natural enemies in home gardens of Batticaloa, Sri Lanka. p. 202-208. In: Proceedings of 10th Annual Research Session, Eastern University, Sri Lanka, 1-2 December 2011.

Silva C.A.D. 2012. Occurrence of new species of mealybug on cotton fields in the States of Bahia and Paraíba, Brazil. Bragantia, Campinas 71 (4): 467-470.

Williams D.J. 1985. Australian Mealybugs. British Museum (Natural History), London, England, $431 \mathrm{pp}$.

Williams D.J., Granara de Willink M.C. 1992. Mealybugs of Central and South America. CAB International, London, England, $635 \mathrm{pp}$. 